\title{
IMPLEMENTASI PERLINDUNGAN HUKUM BAGI KREDITOR DALAM PEMBERIAN KREDIT MODAL KERJA TANPA AGUNAN (STUDI DI DANAMON SIMPAN PINJAM UNIT TUREN)
}

\author{
Muhammad Hatta Pratama
}

CV. Barasandi Batu Bara

J1. Jakarta Blok B1 Nomor 20 Samarinda

Email: htapratama85@gmail.com

\begin{abstract}
This paper aims to identify and analyze the implementation of legal protection for creditors in the provision of working capital loans without collateral. Writing method used is the juridical empirical approach to legislation. There are two forms of legal protection for creditors in lending without collateral. First Protection preventive law, the agreement required binding for both parties in order to avoid losses in case of bad credit that can later be used as the basis for billing when the bad loans. Second, repressive legal protection, which is necessary to the protection of a special court handling problems of small banks with low cost considering the amount of credit granted is not too large.
\end{abstract}

Key words: legal protection, personal loan, creditors, debitors

\begin{abstract}
Abstrak
Tulisan ini bertujuan untuk mengetahui dan menganalisis implementasi perlindungan hukum bagi kreditor dalam pemberian kredit modal kerja tanpa agunan. Metode penulisan yang digunakan adalah yuridis empiris dengan pendekatan perundang-undangan. Ada dua bentuk perlindungan hukum bagi kreditor dalam pemberian kredit tanpa agunan. Pertama Perlindungan hukum preventif, diperlukan isi perjanjian yang mengikat bagi kedua belah pihak guna menghindari kerugian apabila terjadi kredit macet yang nantinya dapat dijadikan dasar untuk penagihan apabila kredit macet. Kedua, Perlindungan hukum Refresif, dimana pada perlindungan ini diperlukan sebuah pengadilan kecil yang khusus menangani permasalahan perbankan dengan biaya yang murah mengingat jumlah kredit yang diberikan tidaklah terlalu besar.
\end{abstract}

Kata kunci: perlindungan hukum, kredit tanpa agunan, kreditor, debitor

\section{Latar Belakang}

Di Indonesia peranan Perbankan sebagai sumber pembiayaan dunia usaha masih sangat dominan. Bank sebagai salah satu lembaga keuangan hadir ditengah masyarakat untuk menyalurkan dana yang dihimpunnya dari masyarakat dan dikembalikan lagi kepada masyarakat dalam bentuk kredit

Kredit dalam kegiatan Perbankan merupakan kegiatan usaha yang paling utama, karena pendapatan terbesar dari usaha Bank berasal dari pendapatan kegiatan 
usaha kredit yaitu berupa bunga dan provisi. Ruang lingkup dari kredit sebagai kegiatan Perbankan, tidaklah semata-mata berupa kegiatan peminjaman kepada nasabah melainkan sangatlah kompleks karena menyangkut keterkaitan unsur-unsur nasabah yang cukup banyak diantaranya meliputi: sumber-sumber dana kreditur, alokasi dana, organisasi dan manajemen perkreditan, kebijakan perkreditan, dokumentasi dan administrasi kredit, pengawasan kredit serta penyelesaian kredit bermasalah. Mengingat begitu luas ruang lingkup dan unsur-unsur yang meliputi kegiatan perkreditan ini, maka tidak berlebihan penangannya pun harus dilakukan secara sangat hati-hati dengan ditunjang profesionalisme serta integritas moral yang harus melekat pada sumber daya manusia dan pejabat perkreditan tersebut.

Suatu kredit mencapai fungsinya apabila secara ekonomis baik bagi debitur, kreditur, maupun masyarakat membawa pengaruh kepada tahapan yang lebih baik, maksudnya baik bagi pihak debitur maupun kreditur mendapatkan kemajuan. Kemajuan tersebut dapat tergambarkan apabila mereka memperoleh keuntungan juga mengalami peningkatan kesejahteraan, dan masyarakat pun atau Negara mengalami suatu penambahan dan peningkatan pajak.

Fungsi utama bank adalah sebagai wahana yang dapat secara optimal menghimpun dana dan selanjutnya secara selektif menyalurkan dana tersebut dalam bentuk kredit kepada para pengusaha sebagai pelaku usaha dan pelaku bisnis yang membutuhkannya. Pihak bank dalam hal ini bank milik Negara ataupun bank yang dikelola oleh pihak swasta sebagai salah satu insan perbankan nasional berusaha untuk membantu kesulitan dana yang dialami oleh para pengusaha sebagai pelaku bisnis.

Lembaga keuangan dalam dunia keuangan bertindak selaku lembaga yang menyediakan jasa keuangan bagi nasabahnya, dimana pada umumnya lembaga ini diatur oleh regulasi keuangan dari pemerintah. Untuk eksistensi Lembaga Keuangan dalam melaksanakan kegiatan usahanya, semua lembaga keuangan wajib menerapkan prinsip kehati-hatian tersebut di atas dalam melaksanakan kegiatan usahanya. Wujud dari penerapan prinsip kehati-hatian, dengan memberlakukan Dasar-Dasar Pemberian Kredit. Prinsip (The five C's of Credit Analysis) merupakan dasar pemberian kredit, yaitu: ${ }^{1}$

a. Caracter (watak)

Sasaran penilian terhadap nasabah (debitur) adalah kemampuan mengendalikan usaha, prospek masa depan usaha, produksi dan pemasaran.

b. Capacity (kemampuan)

Sasaran penilaian terhadap nasabah (debitur) adalah kemampuan mengendalikan usaha, prospek masa depan usaha, produksi dan pemasaran.

c. Capital (modal)

Kredit bank pada dasarnya hanya merupakan modal tambahan. Nasabah (debitur) harus sudah mempunyai modal awal tergantung dari jenis kegiatan usaha. Namun biasanya besar modal

1 Budi Untung, Kredit Perbankan di Indonesia, Andi, Yogyakarta, 2000, hlm. 3. 
awal minimum 20 persen dari total dana yang dibutuhkan.

d. Collateral (agunan/jaminan)

Jaminan merupakan salah satu unsur perjanjian kredit, jaminan diperlukan untuk memberikan keyakinan pada bank bahwa nasabah (debitur) sanggup mengembalikan pinjaman sesuai dengan perjanjian. Oleh karena itu besarnya jaminan dalam perjanjian kredit minimal 100 persen dari nilai kredit.

e. Condition of economy (kondisi perekonomian/prospek usaha debitur)

Penilaian diutamakan pada situasi dan kondisi politik, sosial, ekonomi, dan budaya yang mempengaruhi keadaan ekonomi dalam kurun waktu tertentu. Keadaan perekonomian disini adalah perekonomian negara, nasabah (debitur), maupun keadaan perekonomian bank pemberi kredit.

Penyaluran kredit golongan mikro, kecil dan menengah menjadi segmen yang diminati baik oleh industri perbankan maupun jasa keuangan non bank lainnya. Beberapa faktor yang mempengaruhi tingginya minat industri keuangan tersebut adalah tingkat risiko kredit yang relatif dapat ditekan, pasar yang cenderung besar dan dapat terus berkembang, serta persyaratan administratif yang cenderung lebih mudah untuk dipenuhi.

Untuk meyalurkan dana yang dihimpun dari masyarakat yang biasa disebut kredit ini, bank dalam hal ini akan menawarkan berbagai jenis kredit sesuai dengan kemampuan nasabahnya itu sendiri. Dalam pelaksanaan pemberian kredit itu, tentunya pihak pemberi kredit, dalam hal ini adalah lembaga keuangan menetapkan persyaratan-persayaratan kepada peminjam atau debitur. Persyaratan itu antara lain adalah perjanjian antara debitur dengan kreditur dan harus dituangkan dalam perjanjian kredit yang baku atau sudah ditetapkan oleh lembaga keuangan itu sendiri.

Penyaluran dana yang dilakukan kepada masyarakat khususnya pengusaha kecil dan ekonomi lemah merupakan kebijakan pemerintah dalam sector Perbankan. Penyaluran dana dapat dilakukan melalui pemberian kredit dengan syarat-syarat yang telah ditentukan, salah satunya adalah jaminan untuk menjamin kepastian pelunasan hutang dari debitur terhadap kreditur bilamana dikemudian hari debitur cidera janji atau wanprestasi. Jaminan kredit merupakan jaminan akan pelunasan kredit yang diberikan kepada debitur dengan cara mengeksekusi objek jaminan kredit.

Adapun kegunaan jaminan kredit adalah untuk: ${ }^{2}$

1. Memberikan hak dan kekuasaan kepada bank untuk mendapatkan pelunasan dari agunan apabila debitur cidera janji, yaitu untuk membayar kembali hutangnya pada waktu yang telah ditetapkan dalam perjanjian;

2. Menjamin agar debitur berperan serta dalam transaksi untuk membiayai usahanya, sehingga kemungkinan untuk meninggalkan usaha atau proyeknya dengan merugikan diri sendiri atau perusahaannya dapat dicegah atau sekurang-kurangnya kemungkinan untuk berbuat demikian dapat diperkecil;

2 C.S.T. Kansil dan Christine S.T.Kansil, Pokok-pokok Pengetahuan Hukum Dagang Indonesia, Sinar Grafika, Jakarta, 2002, hlm. 320. 
3. Memberikan dorongan kepada debitur untuk memenuhi janjinya, khususnya mengenai pembayaran kembali sesuai dengan syarat-syarat yang telah disetujui agar debitur dan/atau pihak ketiga yang ikut menjamin tidak kehilangan kekayaan yang telah dijaminkan kepada bank.

Sesungguhnya pemberian kredit yang aman bagi kreditur adalah pemberian kredit yang menggunakan jaminan atau agunan. Benda yang paling umum dipergunakan sebagai jaminan dalam fasilitas pemberian kredit berupa tanah, sebab tanah pada umumnya mudah dijual dan secara ekonomis harganya terus meningkat dibandingkan dengan benda jaminan yang bukan tanah, dan tanah dapat dibebani dengan hak tanggungan.

Pengertian Hak Tanggungan adalah bertitik tolak dari Undang-Undang No. 5 tahun 1960 sebagai Peraturan Dasar Pokok-Pokok Agraria. Dalam Undang-Undang No. 5 Tahun 1960 apa yang dimaksud dengan pengertian dari hak tanggungan tidak dijumpai, selain didalam Pasal 51 yang dikatakan bahwa hak tanggungan yang dapat dibebankan pada Hak Milik, Hak Guna Usaha dan Hak Guna Bangunan tersebut dalam Pasal 25, 33, dan 39 diatur dengan undang-undang itu. Dengan mulai berlakunya Undang-Undang No 4 Tahun 1996 tentang Hak Tanggungan, merupakan satu-satunya lembaga hak jaminan atas tanah dalam Hukum Tanah Nasional yang tertulis. Hak tanggungan sebagai salah satu jenis hak kebendaan, yang bersifat terbatas, yang hanya memberikan kewenangan kepada pemegang haknya untuk pelunasan piutangnya secara mendahulu dari kreditur-kreditur lainnya. ${ }^{3}$

Danamon Simpan Pinjam merupakan salah satu bentuk layanan dari Bank Danamon untuk pengusaha mikro, kecil dan menengah.. Untuk selalu memberikan kemudahan, kecepatan dan kenyaman layanan, Danamon Simpan Pinjam terdiri dari 2 unit layanan bisnis yang telah disesuaikan dengan kebutuhan nasabah sebagai berikut:

\section{Unit Pasar Model}

Fokus melayani nasabah di komunitas Pasar Inti dan Plasma artinya para nasabahnya hanya para pedagang atau orang yang punya usaha diarea pasar, didalam maupun diluar pasar yang terkena retribusi pasar. Unit Pasar Model melayani individu dengan usaha sendiri yang bersifat informal dengan kebutuhan pembiayaan maksimal Rp 500.000.000, Unit Pasar Model memberikan kredit dengan menggunakan jaminan seperti kredit pada umumnya.

2. Unit Solusi Modal

Fokus melayani individu yang memiki usaha sendiri yang berada di luar komunitas pasar (di luar pasar model), dengan target utama para pengecer/ retailer. Kebutuhan pembiayaan yang diberikan maksimal Rp.50.000.000, dan produk Solusi Modal ini memberikan kredit tanpa agunan dengan jangka waktu 36 bulan.

3 Boedi Harsono, Hukum Agraria Indonesia, Djambatan, Jakarta, 2003, hlm. 419. 
Perkembangan Usaha Kecil Menengah (UKM) di Indonesia kian meningkat dan kini mencapai 55,2 juta yang tersebar di seluruh Indonesia. Memahami hal ini masyarakat membutuhkan suatu layanan dan persyaratan yang sederhana, proses yang mudah dan cepat, serta kenyamanan transaksi yang dapat dilakukan di tempat usaha mereka. Oleh karena itu, pada tahun 2004 Danamon Simpan Pinjam hadir untuk memberikan layanan secara khusus bagi usaha dengan skala mikro dan kecil.

Wujud pelaksanaan Danamon Simpan Pinjam dalam memberikan layanan khusus pada pengusaha dengan skala mikro dan kecil adalah dengan pemberian modal kerja. Modal Kerja adalah dana yang ditanamkan dalam aktiva lancar, oleh karena itu dapat berupa kas, piutang, surat-surat berharga, persediaan dan lain-lain. Dalam penelitian ini modal kerja adalah fasilitas kredit yang kepada debitur yang digunakan untuk menambahkan dana dalam aktiva lancar.

Pada pelaksanaan pemberian kredit yang terjadi di Danamon Simpan Pinjam Unit Turen Kabupaten Malang ternyata dalam proses pemberian kreditnya tanpa menggunakan agunan, Hal ini sesuai dengan hasil pra survey peneliti di Danamon Simpan Pinjam: ${ }^{4}$

"Dalam penyaluran kredit, kami sangat berhati-hati, mengingat kami tanpa agunan disini, Dana pinjaman tersebut diberikan kepada calon debitur yang memiliki track- record yang baik di bank maupun di lembaga keuangan. Pinjaman juga tidak banyak minimal 5.000.000 dan paling banyak 50.000.000,-.

Dari pernyataan tersebut dapat disimpulkan dalam pemberian kredit, Dana pinjaman tersebut diberikan kepada calon debitur yang memiliki track-record yang baik di bank maupun di lembaga keuangan lainnya. Pinjaman juga tidak banyak minimal $\mathrm{Rp}$ 5,000,000 dan paling banyak Rp 50.000.000.

Solusi Modal adalah salah satu produk Danamon Simpan Pinjam. Solusi Modal merupakan Pinjaman jangka pendek tanpa jaminan untuk modal usaha atau keperluan lainnya, Jangka waktu pinjaman: 6 - 36 bulan, Besar pinjaman: 5 - 50 juta, Waktu pencairan: 2 hari kerja sejak dokumen diterima lengkap.

Dalam perkembangannya, produk kredit dengan berbasis agunan asset dirasakan tidak memadai dengan kebutuhan pasar karena adanya pertimbangan keterbatasan calon debitur yang tidak mempunyai asset yang layak untuk dipergunakan sebagai agunan. Berdasarkan pada problema yang terdapat dalam kredit dengan agunan maka Danamon Simpan Pinjam mengarahkan bisnisnya pada kredit tanpa agunan. Kebijakan bisnis ini tentunya telah diperhitungkan untuing ruginya terutama terkait manajemen risiko yang terkait dengan kredit tanpa agunan.

Menjadi permasalahan dalam kredit tanpa agunan adalah dalam hal debitur gagal bayar (wanprestasi) atas kredit atau fasilitas

4 Wawancara dengan Hendra, Staf Kredit danamon Simpan Pinjam Unit Turen Kabupaten Malang, 15 April 2013. 
yang diterimanya dari perbankan dimana: (i) dalam hal perbankan telah mendapat agunan dari debitur dalam bentuk asset, maka perbankan dapat mengeksekusi atau menjual asset yang secara khusus dan spesifik telah diagunkan tersebut guna mendapatkan pembayaran atasnya; sedangkan (ii) dalam hal kredit atau fasilitas diberikan tanpa agunan, maka perbankan, seharusnya dapat meminta pembayaran dari debitur dan bila diperlukan akan menjual seluruh asset yang dimiliki oleh debitur dengan batasan dan ketentuan yang diatur oleh peraturan yang ada guna mendapatkan pembayaran.

Berdasarkan hasil wawancara dengan salah satu staf bagian kredit yang menyebutkan bahwa dalam kurun waktu awal tahun 2012 sampai dengan bulan Maret 2013 ini untuk unit nya sendiri sudah menyalurkan kredit kepada masyarakat sebesar Rp. 4.000.000.000 dan besaran nilai kredit yang dinyatakan bermasalah mencapai Rp. 1.000.000.000, dengan rincian nasabah yang menunggak 1 hari sampai yang dalam proses tutup buku. ${ }^{5}$

Hal lain yang perlu diketahui dari Fasilitas kredit tanpa agunan adalah biasanya diberikan dengan bunga yang lebih tinggi dari kredit dengan agunan lainnya. Hal ini dikarenakan resiko yang akan ditanggung oleh perbankan akan lebih besar karena tidak adanya agunan yang secara khusus dan spesifik diberikan oleh debitur sehingga perbankan tidak bisa secara segera mengeksekusi agunan untuk mendapatkan pembayaran.

Dalam pemberian kredit tanpa agunan oleh bank kepada debitur sebenarnya mengandung banyak resiko bagi bank itu sendiri. Adapun resiko yang akan diterima oleh bank adalah misalnya nasabah yang wanprestasi, nasabah yang menghilang, nasabah yang menyalahgunakan kreditnya, serta nasabah yang meninggal dunia. Atas resiko-resiko yang diterima bank tersebut, pihak bank tidak dapat melakukan eksekusi atau sita terhadap benda jaminan nasabah, hal ini disebabkan karena tidak adanya jaminan dalam pemberian kredit tanpa agunan ini sehingga pengembalian kreditnya menjadi terhambat.

Melihat dari permasalahan tersebut diatas bahwa dalam penyaluran kredit modal kerja tanpa agunan ini sendiri di dalam undangundang Perbankan yang berlaku sekarang belum ada yang mengatur secara khusus tentang pemberian kredit tanpa agunan ini. Dan Bank Indonesia selaku bank sentral pun belum mengeluarkan kebijakan tentang pengaturan kredit tanpa agunan ini.

Presiden Direktur PT Bank Central Asia Tbk, Jahja Setiadjmaja mengatakan etika penawaran Kredit Tanpa Agunan perlu diseragamkan dimana perlu aturan dari Bank Indonesia. "Perlu etika, dan BI yang atur. Artinya perbankan jangan asal menawarkan KTA karena tanpa agunan maka risiko kredit ini besar dan dapat menyebabkan rasio kredit macet (Non Performing Loan/NPL) tinggi,". ${ }^{6}$

5 Wawancara dengan Staf Kredit danamon Simpan Pinjam, 15 April 2013.

6 Herdaru Purnomo, BI Didesak Keluarkan Aturan Etika Penawaran KTA, http//detikFinance.co.id, diakses 12 Agustus 2011 pukul 09.10 WIB. 
Seharusnya ada yang mengatur tentang bagaimana sistem penyaluran kredit yang lebih hati-hati (prudent) dan tepercaya, bagaimana cara penagihannnya. Fokus penyaluran kredit tanpa agunan yang mengedepankan prinsip kehati-hatian diharapkan selain dapat menghindari kredit macet (non performing loan/ NPL) dan fraud (penggelapan dana).

Berdasarkan uraian latar belakang masalah di atas, maka dapat dirumuskan permasalahan yang akan menjadi pokok pembahasan adalah Bagaimana perwujudan perlindungan hukum bagi kreditor dalam pemberian kredit modal kerja tanpa agunan.

Jurnal ini didasarkan pada penelitian hukum yuridis sosiologis (empiris), yaitu suatu penelitian yang menggunakan bahan kepustakaan atau data sekunder sebagai data awalnya kemudian dilanjutkan dengan pengambilan data primer atau data lapangan. Pengumpulan data dilakukan secara langsung di lapangan, yaitu pengumpulan data primer menggunakan teknik wawancara terstruktur dengan nara sumber, dalam hal ini pihak bank. Sedangkan data sekunder diperoleh dengan membaca buku-buku literatur yang ada, perundang-undangan, internet dan sumbersumber lain yang berhubungan dengan tulisan ini.

Pendekatan yang digunakan di dalam penelitian adalah pendekatan perundangundangan (Statute Approach). Pendekatan perundang-undangan digunakan untuk mengkaji dan analisis terhadap perjanjian kredit tanpa agunan dan peraturan perundang- undangan yang berhubungan dengan tema penelitian, yakni Undang-undang Negara Republik Indonesia Nomor 10 Tahun 1998 Tanggal 10 November 1998 tentang Perubahan Undang-undang Nomor 7 Tahun 1992 Tentang Perbankan, khususnya Pasal 2 UU No. 10 Tahun 1998.

\section{Pembahasan}

\section{A. Penerapan Prinsip Kehatian- hatian dalam Pemberian Kredit Modal Kerja Tanpa Agunan}

Pemberian kredit dapat diberikan oleh lembaga keuangan perbankan maupun lembaga keuangan non-perbankan, namun demikian untuk lembaga perbankan pemberian kredit dilakukan berdasarkan syarat-syarat yang cukup sulit. Akan tetapi Danamon simpan pinjam juga memberikan pinjaman kepada debitur tanpa melalui agunan. Pemberian kredit tersebut terkesan sangat mudah bahkan tidak jarang terkesan sangat dipaksakan karena dalam pencairan kredit kepada masyarakat tersebut tidak melalui suatu penelitian yang mendalam yang tentunya juga membutuhkan waktu baik administrasi maupun dalam mengambil kesimpulan sebelum mencairkan kredit.

\section{Menurut Ilmu Ekonomi Perbankan} terdapat suatu asas yang harus diperhatikan oleh bank sebelum memberikan kredit kepada nasabahnya, yaitu yang dikenal dengan istilah The Five C's of Credit, artinya pada pemberian kredit tersebut harus memperhatikan 5 (lima) 
faktor, yaitu: ${ }^{7}$ Character (watak), Capacity (kemampuan), Capital (modal), Condition of Economic (suasana perkembangan ekonomi), Colleteral (jaminan).

Jadi dalam hal ini pemberian kredit biasanya mengunakan jasa petugas lapangan yang dipercaya oleh bank adalah merupakan wewenang sepenuhnya dari petugas lapangan, sehingga dengan keleluasan tersebut petugas lapangan terkesan ceroboh di dalam memberikan kredit kepada masyarakat karena adanya dorongan untuk mendapat nasabah yang sebanyak-banyaknya berkaitan dengan imbalan yang diterimanya dari sebuah bank dimana dia bekerja.

Prinsip kehati-hatian (prudent banking principle) adalah suatu asas atau prinsip yang menyatakan bahwa dalam menjalankan fungsi dan kegiatan usahanya wajib bersikap hatihati (prudent) dalam rangka melindungi dana masyarakat yang dipercayakan padanya. $^{8}$ Hal ini disebutkan dalam Pasal 2 UU Nomor 10 Tahun 1998 bahwa perbankan Indonesia dalam melakukan usahanya berasaskan demokrasi ekonomi dengan menggunakan prinsip kehatihatian.

Dalam penjelasan Pasal 2 UU Perbankan, dijelaskan bahwa yang dimaksud dengan "Prinsip kehati-hatian" adalah pedoman pengelolaan Bank yang wajib dianut guna mewujudkan perbankan yang sehat, kuat, dan efisien sesuai dengan ketentuan peraturan perundang-undangan.

1. Dalam rangka menjalankan asas Prinsip kehati hatian ini, pengelolaan sebuah bank secara baik berdasarkan prinsipprinsip perbankan yang sehat dan dinamis (prudential banking), harus dilakukan beberapa langkah sebagai berikut:

a. Perumusan kebijaksanaan bank Secara ringkas ada dua macam kebijaksanaan bank yang perlu diperhatikan dengan sungguhsungguh, yaitu:

1. Kebijaksanaan yang dirumuskan sesudah pertimbangan-pertimbangan yang matang terhadap konsekuensi dari semua pilihan yang tersedia.

2. Kebijaksanaan yang timbul dari tunggal atau berulang-ulang. Dalam prudential banking, Dewan Komisaris mempunyai kedudukan yang penting. Mereka bertugas tidak hanya melakukan pengawasan umum atau mengawasi kebijaksanaan, tetapi juga melakukan analisis atas berbagai masalah bank dan memberikan masukan-masukan penting bagi direksi dan staf-staf operasional.

2. Penyusunan rencana pengembangan organisasi Pada dasarnya, perencanaan organisasi atau mengevaluasi organisasi

7 Purwahid Patrik dan Kashadi, Hukum Jaminan edisi Revisi dengan UUHT, Fakultas Hukum Universitas Diponegoro, 2003, hlm. 92.

8 Rachmadi Usman, Aspek-aspek Hukum Perbankan di Indonesia, Gramedia Pustaka Utama, Jakarta, 2001, hlm. 18. 
yang ada adalah pembagian kerja (division of work) yang logis, penetapan garis wewenang yang jelas, pengukuran pelaksanaan dan prestasi. Melalui perencanaan yang demikian akan dapat dibuat struktur organisasi yang sehat dan efektif. Bagi bank-bank yang telah berjalan, dapat pula dilakukan reorganisasi guna penyesuaian organisasi pada kebutuhan bisnis masa kini.

3. Staffing dan pengembangan manajerial skill Perencanaan manajemen bukanlah melaksanakan sendiri pemecahan masalah-masalah tertentu yang dihadapi, melainkan mengawasi bahwa tindakantindakan yang semestinya telah dilaksanakan oleh orang-oranag lain dengan cara yang teratur, efektif dan continue.

4. Pengawasan internal Kelancaran operasional bank adalah kepentingan paling utama dari direksi (top manajemen) melalui pengawasan, para manejer dapat menentukan tercapai tidaknya harapan mereka. Di samping itu, pengawasan ini dapat membantu manajer mengambil keputusan yang lebih baik.

5. Penetapan sistem manajemen Sistem manajemen yang kita maksudkan dalam pembahasan ini adalah berhubungan dengan tata cara bank mengatur pola operasional dari berbagai aktivitas bank. Pola ini erat pula dengan sistem sentralisasi maupun desentralisasi.
6. Sound banking business sebagai suatu sistem universal yang harus diikuti oleh manajemen bank. Sebagai agent of development, bank tidak sematamata mengejar profit, tetapi juga memperhatikan prioritas-prioritas pembiayaan pembangunan nasional sesuai dengan tahap-tahap yang ditetapkan. dengan demikian, bank sebagai lembaga keuangan yang berfungsi sebagai financial intermediary atau perantara keuangan dari dua pihak, yakni pihak yang kelebihan dana dan pihak yang kekurangan dana hendaklah memperhatikan prinsip-prinsip tersebut di atas dalam rangka melindungi pihak yang berkaitan dengannya.

Ada satu pasal dalam UU Perbankan yang secara eksplisit mengandung subtansi prinsip kehati-hatian, yakni Pasal 29 ayat (2), (3) dan (4) UU Nomor 10 Tahun 1998 yang berbunyi:

(2) Bank wajib memelihara tingkat kesehatan bank sesuai dengan ketentuan kecukupan modal, kualitas aset, kualitas manajemen, likuiditas, rentabilitas, solvabilitas, dan aspek lain yang berhubungan dengan usaha bank dan wajib melakukan kegiatan usaha sesuai dengan prinsip kehati-hatian.

(3) Dalam memberikan kredit atau pembiayaan berdasarkan prinsip syariah dan melakukan kegiatan usaha lainnya, bank wajib menempuh cara-cara yang tidak merugikan bank dan kepentingan nasabah yang mempercayakan dananya kepada bank.

(4) Untuk kepentingan nasabah, bank wajib menyediakan informasi mengenai 
kemungkinan timbulnya risiko kerugian sehubungan dengan transaksi nasabah yang dilakukan melalui bank.

Kredit sendiri dalam kegiatan perbankan merupakan kegiatan usaha yang paling utama karena pendapatan terbesar dari usaha bank berasal dari pendapatan kegiatan usaha kredit, yaitu berupa bunga dan provisi. Oleh karena itu, usaha perkreditan membutuhkan penanganan yang profesional dengan integritas moral yang tinggi. Hal demikian tidak berlebihan karena akar dari pengertian kredit itu sendiri adalah kepercayaan. Kosakata kredit berasal dari bahasa Romawi, yaitu dari kosakata "credere" yang berarti percaya. Dengan demikian, dasar pengertian dari istilah atau kosakata kredit yaitu kepercayaan sehingga hubungan yang terjalin dalam kegiatan perkreditan di antara para pihak, sepenuhnya harus juga didasari oleh adanya saling mempercayai, yaitu bahwa kreditur yang memberikan kredit percaya bahwa penerima kredit akan sanggup.

Istilah perjanjian kredit ditemukan dalam instruksi pemerintah yang ditujukan kepada masyarakat bahwa memberi kredit dalam bentuk apapun bank-bank wajib mempergunakan "akad perjanjian "instruksi demikian dimuat dalam instruksi presiden kabinet No 15/EKA/10/1996 jo Surat Edaran Bank Negara Indonesia No.2/539/Upk/ Pemb/1996 dan Surat edaran Bank Negara Indonesia No.2/643/UPK/Pemb/1960 tentang pedoman kebijaksanaan dibidang perkreditan.
Bank yang pada hakikatnya merupakan lembaga intermediasi di mana di satu sisi ia menampung dana dari masyarakat dalam bentuk tabungan dan di sisi lain ia juga menyalurkan dana tersebut kepada masyarakat dalam bentuk kredit. Sebagai pemberi kredit, bank wajib menetapkan suatu kebijakan perkreditan agar tetap dapat memelihara keseimbangan yang tepat antara keinginan untuk memperoleh keuntungan dan menjamin lunasnya semua kredit yang disalurkan. Seperti dalam ketentuan Pasal 8 Undang-undang perbankan disebutkan bahwa bank dalam memberikan kreditnya wajib mempunyai keyakinan berdasarkan analisis yang mendalam atas itikad baik dan kemampuan serta kesanggupan nasabah debitur untuk melunasi hutangnya. Dalam hal tersebut, pihak bank telah mensyaratkan adanya jaminan yang mempunyai bentuk yang baik yang biasanya berbentuk agunan, ini dilakukan karena kredit yang diberikan oleh bank mengandung resiko9 .

Tetapi saat ini beberapa bank telah berani untuk memberikan kredit tanpa menggunakan agunan. Keadaan ini dipicu oleh situasi perekonomian di Indonesia yang hingga kini belum menentu, sehingga perbankan kini mulai melirik ke sektor konsumsi.

Danamon Simpan Pinjam sebagai salah satu bank di Indonesia juga mengeluarkan produk kredit individual tanpa agunan yang dikhususkan kepada siapa saja untuk

9 http://www.digilib.ui.ac.id, diakses 14 Nopember 2013. 
mendapatkan kredit modal kerja. Walaupun dalam pemberian kredit semacam ini mengandung resiko yang cukup besar, tetapi Danamon Simpan Pinjam telah mempersiapkan pagar-pagar hukum yang cukup kuat untuk diberikan kepada nasabahnya dengan penyeleksian yang ketat terhadap calon nasabahnya. Dengan demikian dapat diminimalisir resiko terjadinya kredit macet dari pemberian kredit individual tanpa agunan. Lahirnya perjanjian kredit memberi konsekuensi kepada kreditur mengenai kepastian hukum bagi kreditur apabila debitur lalai dalam memenuhi kewajibannya kepada kreditur. ${ }^{10}$

Pada kenyataannya, dalam praktek pemberian kreditolehbank, agunan(collateral) selalu menjadi faktor pertimbangan yang paling menentukan untuk dapat dikabulkannya permohonan kredit dari masyarakat (debitur). Kredit yang diberikan kepada debitur harus diamankan, dalam arti harus dapat dijamin pengembalian atau pelunasannya. Dalam rangka memberikan keamanan dan kepastian pengembalian kredit dimaksud, kreditur perlu meminta agunan untuk kemudian dibuatkan perjanjian pengikatannya. ${ }^{11}$

Menurut Johannes Ibrahim, bahwa dalam hubungannya dengan pemberian kredit, jaminan hendaknya dipertimbangkan mengingat dua faktor, yaitu:
1. Secured, artinya jaminan kredit dapat diadakan pengikatan secara yuridis formal, sesuai dengan ketentuan hukum dan perundang undangan. Jika di kemudian hari terjadi wanprestasi dari debitur, maka pemberi kredit memiliki kekuatan yuridis untuk melakukan tindakan eksekusi.

2. Marketable, artinya jaminan tersebut bila hendak dieksekusi dan segera dijual atau diuangkan untuk melunasi seluruh kewajiban debitur. ${ }^{12}$

Prinsip kehati-hatian atau yang dalam istilah lain disebut dengan banking prudential principles merupakan prinsip yang umum yang digunakan dalam kegiatan atau aktivitas perbankan. Salah satunya adalah melalui pengawasan, yakni sampai sejauh mana bank diawasi kegiatan dengan menggunakan prinsip kehati-hatian sebagai tolok ukur utama. Namun, pengawasan perbankan pada umumnya merupakan tindakan represif yang tidak cukupmencegah terjadinyakebangkrutan bank atau likuidasi atau pembekuan kegiatan usaha dan ditempatkannya bank dalam pengawasan khusus di masa industri perbankan di tahun 2004. Bahkan bank-bank tersebut bangkrut karena "dirampok" oleh pemilik dan atau pengurusnya sendiri dan pengawas “terlambat" mengetahuinya. Beberapa studi memang meragukan efektifitas aturan kehatihatian (prudential regulation) dan kinerja lembaga pengawas. Pendekatan alternatif

10 Sutarno, Aspek-aspek Hukum Perkreditan pada Bank, Alfabeta, Bandung, 2000, hlm. 92.

11 Muhammad Djumhana, Hukum Perbankan di Indonesia, Citra Aditya Bakti, Bandung, 2000, hlm. 397.

12 Johannes Ibrahim, Cross Default dan Cross Collateral sebagai Upaya Penyelesaian Kredit Bermasalah RefikaAditama, Bandung, 2004, hlm. 71. 
yang ditawarkan adalah menerapkan sunshine regulation (aturan keterbukaan). Tujuannya adalah untuk meningkatkan kemampuan nasabah dan stakeholder lainnya mengawasi bank secara langsung. ${ }^{13}$ Aspek keterbukaan yang dilakukan perbankan menjadi bagian yang tidak terpisahkan dalam setiap aktivitas perbankan di Indonesia.

Dapat diketahui bahwa prinsip kehatihatian yang dicantumkan dalam undangundang perbankan tidaklah cukup untuk membantu pelaku-pelaku perbankan dalam melakukan aktivitas yang berkaitan dengan sistem keuangan bank. Masyarakat perbankan kemudian harus menerjemahkan maksud dari prinsip kehati-hatian yang dituangkan dalam peraturan perbankan. Hal inilah yang kemudian menjadi kebiasaan-kebiasaan baru yang dilakukan dalam dunia perbankan di Indonesia, yakni misalnya bank dengan sengaja secara terbuka memberikan informasi yang seluas-luasnya mengenai kegiatan yang dilakukannya kepada masyarakat. Keterbukaan tersebut kemudian dikenal dengan transparansi perbankan.

Transparansi perbankan kemudian menjadi suatu fenomena baru di dunia perbankan belakangan ini di Indonesia. Suatu kesadaran umum yang dipahami oleh pelakupelaku usaha perbankan dan nasabah adalah bahwasanya aturan mengenai prinsip kehatihatian sangat kabur dan solusinya harus diterjemahkan secara luas. Transaparansi perbankan sendiri sangat erat kaitannya dalam informasi perbankan yang selalu berkembang menuruti keinginan pasar. Oleh karena itu, sistem keuangan di bidang perbankan dengan cepat memberikan respon yang baik terhadap transparansi perbankan. Apabila sistem keuangan tidak bekerja dengan baik, maka perekonomian menjadi tidak efisien dan pertumbuhan ekonomi yang diharapkan tidak akan tercapai.

Salah satu masalah krusial dalam sistem keuangan yang dapat menjadi sumber instabilitas keuangan yakni menyangkut terjadinya asimetri / ketidaksamaan informasi

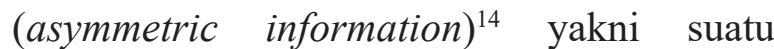
situasi dimana satu pihak yang terlibat dalam kesepakatan keuangan tidak memiliki informasi yang akurat dibanding pihak lain. sebagai contoh, peminjam (debitur) biasanya memiliki informasi yang lebih baik keuntungan dan kerugian potensial dari suatu proyek investasi yang direncanakan dibandingkan dengan pihak pemberi pinjaman (kreditur). Dengan demikian, kreditur tidak dapat membedakan antara pinjaman yang sehat dan tidak sehat. ${ }^{15}$ Hal inilah yang semata-mata dapat mengesampingkan prinsip

13 Zulkarnain Sitompul, Transparansi Perbankan: Tantangan 2005, Pilars N0.51/TH VII/27 Desember 2004 09 Januari 2005, hlm. 1.

14 Frederic S. Mishkin dalam "Prudential Supervision Whal Works and What Doesn't”, NBER Conference Report. Chicago, The University of Chicago Press, 2001.

15 Anwar Nasution, Masalah-masalah Sistem Keuangan dan Perbankan Indonesia. Makalah yang disampaikan dalam Seminar Pembangunan Hukum Nasional VIII yang diselenggarakan oleh Badan Pembinaan Hukum Nasional - Departemen Kehakiman dan Hak Asasi Manusia R1, 14-18 Juli di Denpasar, hlm. 2 . 
kehati-hatian, atau dengan kata lain prinsip ini menjadi tidak tepat guna pada upaya pencegahan kebangkrutan bank.

Dalam pemberian kredit tanpa agunan oleh bank kepada debitur sebenarnya mengandung banyak resiko bagi bank itu sendiri. Adapun resiko yang akan diterima oleh bank adalah misalnya nasabah yang wanprestasi, nasabah yang menghilang, nasabah yang menyalahgunakan kreditnya, serta nasabah yang meninggal dunia. Atas resiko-resiko yang diterima bank tersebut, pihak bank tidak dapat melakukan eksekusi atau sita terhadap benda jaminan nasabah, hal ini disebabkan karena tidak terpenuhinya salah satu unsur yaitu adanya jaminan dalam pemberian kredit tanpa agunan ini sehingga pengembalian kreditnya menjadi terhambat dan pihak bank selaku kreditor tidak dapat berbuat apa-apa.

Dari gambaran penjelasan di atas terkait pejanjian kredit tanpa agunan yang diterapkan oleh Bank Danamon Simpan Pinjam bertentangan dengan prinsip kehatihatian Bank, sebagaimana disebutkan dalam Pasal 2 undang-undang Nomor 10 Tahun 1998 tentang Perubahan atas Undang-Undang Nomor 7 Tahun 19092 Tentang Perbankan yaitu: Perbankan Indonesia dalam melakukan usahanya berasaskan demokrasi ekonomi dengan menggunakan prinsip kehati-hatian.

Danamon Simpan Pinjam sendiri mengantisipasi pemberian kredit nya yang tanpa agunan dengan memberikan bunga yang tinggi untuk mengcover dana yang keluar yaitu 49,9218\% Efektif pertahun, setara dengan $30 \%$ flat pertahun, ini berbeda jauh dengan bank pemerintah pada umumnya yang hanya 13-14 \% pertahun. Keutungan Danamon Simpan Pinjam pertahunnya sudah dihitung secara nasional akan menutupi jumlah kerugian yang akan diderita Danamon Simpan Pinjam, dengan estimasi keuntungan nasional pertahun dibagi dengan kerugian nasional pertahunnya. Sehingga Danamon Simpan Pinjam masih bisa sampai saat ini menjalankan produk usahanya yang tanpa agunan ini.

\section{B. Pertimbangan Hukum Pemberian Kredit Modal Kerja Tanpa Agunan}

Pemberian kredit merupakan kegiatan utama bank yang mengandung resiko yang dapat mempengaruhi kesehatan dan kelangsungan usaha bank, sehingga dalam pelaksanaanya bank harus berdasarkan asasasas perkreditan. Faktor penting yang harus diperhatikan oleh bank untuk mengurangi resiko tersebut adalah keyakinan atas kemampuan dan kesanggupan debitur untuk melunasi utangnya sesuai dengan yang diperjanjikan. Untuk memperoleh keyakinan tersebut, sebelum memberikan kredit, bank harus melakukan penilaian yang seksama terhadap watak, kemampuan, modal, agunan, dan prospek usaha debitur ${ }^{16}$.

16 Permadi Ganda Pradja, Dasar dan Prinsip Pengawasan Bank, Gramedia Pustaka Utama, Jakarta, 2004, hlm. 21. 
Dalam rangka mendukung upaya tersebut di atas, peranan Kebijaksanaan Perkreditan Bank (KPB) sangat penting karena berfungsi sebagai panduan dalam pelaksanaan semua kegiatan yang terkait dengan perkreditan yang sehat dan menguntungkan bagi bank. Bank diharapkan dapat menerapkan asas-asas perkreditan yang sehat secara konsisten dan berkesinambungan

Dalam dunia perbankan istilah agunan lebih sering digunakan daripada istilah jaminan. Agunan merupakan jaminan tambahan yang diperlukan dalam hal pemberian fasilitas kredit. Dalam Pasal 2 ayat (1) Surat Keputusan Direksi Bank Indonesia Nomor 23/69/KEP/DIR tanggal 28 Pebruari 1991 yang mengatur bahwa agunan sebagai salah satu unsur pemberian kredit, maka apabila berdasarkan unsur-unsur lain telah dapat diperoleh keyakinan atas kemampuan nasabah debitur mengembalikan utangnya, agunan dapat hanya berupa barang, proyek, atau hak tagih yang dibiayai dengan kredit yang bersangkutan. Dengan demikian mengenai kedudukan jaminan hingga pentingnya jaminan dalam pemberian kredit oleh bank. Agar penerapan jaminan dalam pemberian kredit dapat berjalan dengan baik, maka dalam undang-undang perbankan secara tegas mengatur tentang jaminan. Dimana aturan hukum tersebut dapat memberikan keamanan bagi para pihak yang terlibat dalam perjanjian kredit, khususnya bagi pihak bank selaku kreditur dan nasabah selaku debitur ${ }^{17}$.

Lembaga keuangan bank mempunyai posisi strategis dalam perekonomian nasional, dan berkaitan dengan ini maka perbankan harus mampu berperan sebagai sarana mobilisasi dana masyarakat yang efektif dan efisien serta sebagai penyalur yang cermat dari dana tersebut untuk kegiatan yang produktif, yang pada gilirannya akan mendukung pelaksanaan pembangunan nasional dalam rangka meningkatkan pemerataan pembangunan dan hasil-hasilnya, pertumbuhan ekonomi dan stabilitas nasional, ke arah peningkatan taraf hidup rakyat banyak. Hal tersebut sangat sesuai dengan pengertian bank yang termuat dalam Pasal 1 angka 2 Undang-undang Nomor 10 Tahun 1998 tentang Perubahan Atas Undang-undang Nomor 7 Tahun 1992 tentang Perbankan, yaitu bank adalah badan usaha yang menghimpun dana dari masyarakat dalam bentuk simpanan dan menyalurkannya kepada masyarakat dalam bentuk kredit dan atau bentuk-bentuk lainnya dalam rangka meningkatkan taraf hidup rakyat banyak. ${ }^{18}$

17 Edy Putra Ije Aman, Kredit Perbankan Suatu Tinjauan Yuridis, Liberty, Yogyakarta, 1989, hlm. 14.

18 Peranan bank sebagai lembaga intermediasi memiliki fungsi sebagai perantara keuangan antar apihak pemilik dana dengan yang memerlukan dana. Hal ini ditegaskan pula dalam Pasal 3 UU Perbankan, yang menyebutkan bahwa fungsi perbankan Indonesia adalah sebagai penghimpun dan penyalur dana masyarakat. Lebih lanjut lagi, Pasal 4 UU Perbankan menyebutkan bahwa Perbankan Indonesia bertujuan menunjang pelaksanaan pembangunan nasional dalam rangka meningkatkan pemerataan, pertumbuhan ekonomi, dan stabilitas nasional kearah peningkatan kesejahteraan rakyat banyak. Dari pengertian kedua pasal tersebut sangat terlihat jelas bahwa bank berfungsi sebagai "financial intermediary" dengan kegiatan usaha pokok menghimpun dan menyalurkan dana masyarakat. 
Dalam perkreditan yang tanpa agunan ini mempunyai banyak kegunaan adalah untuk: ${ }^{19}$

1. Memberikan hak dan kekuasaan kepada bank untuk mendapat pelunasan dari agunan apabila debitur melakukan cidera janji, yaitu untuk membayar kembali utangnya pada waktu yang telah ditetapkan dalam perjanjian.

2. Menjamin agar debitur berperan serta dalam transaksi untuk membiayai usahanya, sehingga kemungkinan untuk meninggalkan usaha atau proyeknya dengan merugikan diri sendiri atau perusahaannya dapat dicegah atau sekurangkurangnya kemungkinan untuk berbuat demikian dapat diperkecil;

3. Memberikan dorongan kepada debitur untuk memenuhi janjinya, khususnya mengenai pembiayaan kembali dengan syarat-syarat yang disetujui agar debitur dan atau pihak ketiga yang ikut menjamin tidak kehilangan kekayaan yang telah dijaminkan kepada bank.

Dasar hukum pemberian kredit tanpa agunan dapat dilihat pada Undang-Undang Perbankan Nomor 10 Tahun 1998, pada pasal 8 ayat 1: "Dalam memberikan kredit atau pembiayaan berdasarkan Prinsip Syariah, Bank Umum wajib mempunyai keyakinan berdasarkan analisis yang mendalam atas itikad dan kemampuan serta kesanggupan nasabah debitur untuk melunasi hutangnya atau mengembalikan pembiayaan dimaksud sesuai dengan yang diperjanjikan.“20
Sutan Remmy Syahdeini memberikan batasan bahwa perjanjian kredit memiliki pengertian secara khusus, yaitu perjanjian antara bank sebagai kreditur dengan nasabah sebagai debitur mengenai penyediaan uang atau tagihan yang dapat dipersamakan dengan itu yang mewajibkan nasabah debitur untuk melunasi hutangnya setelah jangka waktu dengan jumlah bunga, imbalan, atau pembagian hasil keuntungan ${ }^{21}$. Dalam hal ini dalam pemberian kredit tanpa jaminan mengandung lebih besar resiko, sehingga dengan demikian berlaku bahwa semua harta kekayaan debitur baik yang bergerak maupun tidak bergerak yang sudah ada maupun yang akan ada kemudian seluruhnya menjadi jaminan pemenuhan pembayaran hutang.

Kredit yang diberikan oleh bank mengandung resiko sehingga dalam pelaksanaannya bank harus memperhatikan Asas-asas Perkreditan yang Sehat. Dengan mengingat hal tersebut maka dalam memberikan kreditnya bank wajib melakukan analisis terhadap kemampuan debitur untuk melaksanakan kewajibannya. Selain itu, bank juga dituntut untuk melakukan peninjauan, penilaian dan pengikatan terhadap agunan yang disodorkan oleh debitur, sehingga agunan yang diterima dapat memenuhi persyaratan ketentuan berlaku².

19 Rahmadi Usman, Op.cit., hlm. 286.

20 Ibid., hlm. 287.

21 Sutan Remmy Syahdeini, Kebebasan Berkontrak dan Perlindungan yang Seimbang bagi Para Pihak dalam Perjanjian Kredit Bank, Institut Bankir Indonesia, Jakarta, 1993, hlm. 34.

22 Mgs. Edy Putra Ije Aman, 1989, Kredit Perbankan Suatu Tinjauan Yuridis, Yogyakarta, Liberty, hlm. 14. 
Kredit tanpa agunanTanpa Agunan ini (KTA) bisa dikatakan sebagai karya inovatif dan cerdik institusi keuangan dalam memasarkan produknya. Dengan tawaran suku bunga kompetitif, tujuan penggunaan bebas, dan proses pengajuan yang cepat dan mudah, makin membuat banyak masyarakat berminat. Besarnya peluang dalam bisnis KTA yang masuk dalam kredit konsumtif ini rupanya juga membuat beberapa bank nasional tergiur mencicipi gurihnya kue KTA. Bank Mandiri misalnya meluncur kan KTA yang diberi nama Kredit Bebas Agunan Mandiri, dengan tawaran proses cepat dan mudah, angsuran yang dapat disesuaikan dengan kemampuan debitur, dan besaran kredit yang ditawarkan mulai dari 5 juta rupiah sampai 200 juta rupiah. Selain itu Bank Negara Indonesia '46 mempunyai produk andalanya itu BNI Flexi yang menawarkan layanan pembiayaan tanpa agunan sampai dengan 30 juta rupiah. Sedangkan Bank Bukopin tanpa mengeluarkan produk KTA berlabel Kredit Serba Guna.

\section{Perlindungan Hukum bagi Kreditor dalam Pemberian Kredit Modal Kerja Tanpa Agunan}

Perkembangan dunia perbankan di Indonesia adalah dinamis, cepat berubah, seiring berkembangnya masyarakat dalam menggunakan media perbankan sebagai upaya pemenuhan kebutuhannya. Pengaturan perbankan di Indonesia sebagai koridor, yakni dengan pemberlakuan UU No. 7 Tahun 1992 tentang Perbankan sebagaimana diubah dengan UU No. 10 Tahun 1998. Di dalam peraturan perundang-undangan tersebut, dimuat ketentuan bahwa Perbankan Indonesia dalam melakukan usahanya berasaskan demokrasi ekonomi dengan menggunakan prinsip kehati-hatian. ${ }^{23}$

Mengutip Seperti apa yang dikatakan oleh Subekti Bahwa I'tikad Baik diwaktu membuat suatu perjanjian berarti kejujuran. Orang yang ber i'tikad baik menaruh kepercayaan sepenuhnya kepada pihak lawan, yang dianggapnya jujur dan tidak menyembunyikan sesuatu yang buruk yang dikemudian hari dapat menimbulkan kesulitan-kesulitan. ${ }^{24}$ Itulah sebuah sangkaan awal dalam mengadakan perjanjian apapun, termasuk perjanjian kredit modal kerja tanpa agunan.

Dalam dunia perbankan sering kali terjadi permasalahan yang memiliki implikasi hukum bagi para pelaku yang bersangkutan. Salah satu di antara permasalahan yang sering terjadi ialah bagaimana sistem kredit yang tidak menggunakan agunan maupun jaminan dan bagaimana perlindungan hukumnya, jaminan dari pihak debitur merupakan persyaratan mutlak dengan tujuan untuk adanya kepastian hukum yang secara tegas telah diatur dalam perjanjian kredit. Hal ini disebabkan karena jaminan merupakan hal yang sangat penting bagi pihak bank untuk menangkal resiko- 
resiko yang mungkin akan timbul di kemudian hari sebagai akibat dari pemberian kredit oleh bank kepada pihak debitur ${ }^{25}$.

Setiap pemberian kredit selalu menuntut pertanggung-jawaban dari pejabat kredit yang memutus baik secara jabatan maupun secara pribadi, sehingga keputusan kredit yang bermasalah dapat diminimalkan sejauh mungkin. Kredit tanpa Agunan mengandung lebih besar resiko, sehingga dengan demikian berlaku bahwa semua harta kekayaan debitur baik yang bergerak maupun tidak bergerak yang sudah ada maupun yang akan ada kemudian seluruhnya menjadi jaminan pemenuhan pembayaran hutang. ${ }^{26}$

Hukum sebagai salah satu norma sosial bertugas membingkai pola-pola yang jumlah dan ragamnya banyak sekali, dan akhirnya hukum itu sendiri memasuki aspek-aspek kehidupan sosial kemasyarakatan yang beraneka pula. Dengan konfigurasi semacam itu, akhirnya dapat dipahami kalau hukum yang ada dan berlaku dalam suatu kehidupan masyarakat pelaksanaannya akan dipengaruhi oleh banyak aspek. ${ }^{27}$

Dalam pokok permasalahan ini bagaimana perwujudan perlindungan hukum bagi kreditor dalam pemberian kredit modal kerja tanpa agunan dan bagaimana hukum sejatinya sebagai taming dalam membatasi manusia yang mengatur kehidupan masyarakat dalam pelaksanaannya sangat bergantung pada aspek-aspek kemasyarakatan, sehingga karenanya tepat apa yang disampaikan oleh W. Friedman; "The self sufficiency of law is an illusion. It is, to use a well known pharase by Moltke, a dream, but not even a beautiful one”. Hukum sebagai norma sosial perkembangannya tidak semata ditentukan oleh hukum itu sendiri, tetapi lebih bergantung pada masyarakat dimana hukum itu berada ${ }^{28}$.

Dalam setiap transaksi yang membuat kesepakatan bersama yang di ikat dengan mengandung implikasi hukum terhadap kedua belah pihak maka kedua belah pihak tersebut wajib mengikuti dan mematuhi apa yang sudah disepakati. Menurut Undang-undang Nomor 7 Tahun 1992 tentang Perbankan, sebagaimana telah diubah dengan Undang-undang Nomor 10 tahun 1998, dalam pasal 1 angka (11) menyebutkan bahwa kredit adalah penyediaan uang atau tagihan yang dapat dipersamakan dengan itu, berdasarkan persetujuan atau kesepakatan pinjam-meminjam antara bank dan pihak lain yang mewajibkan pihak peminjam untuk melunasi utangnya setelah jangka waktu tertentu dengan jumlah bunga ${ }^{29}$.

Pasal 1338 ayat (1) Kitab Undang-undang Hukum Perdata (KUH Perdata) menyatakan bahwa semua kontrak atau perjanjian yang dibuat secara sah berlaku sebagai undang-

25 R. Tjipto adi nugroho, Perbankan, Masalah Fungsi, Organisasi dan Ketatalaksanaan, Pradnya Paramita, Jakarta, 1986, hlm. 66.

26 Munir Fuady, Jaminan Fidusia, Cetakan Ke-dua Revisi, Citra Aditya, Bandung, 2003, hlm. 19.

27 B. Curzon, Jurisprudence, Macdonal \& Evan Ltd, Estover Plymouth, 1979, hlm. 148.

28 Ibid., hlm. 149.

29 Subekti, Op.cit., hlm. 17. 
undang bagi mereka yang membuatnya atau biasa dikenal dengan asas Pacta Sunt Servanda. Dari pasal ini dapat disimpulkan adanya asas kebebasan berkontrak, akan tetapi kebebasan ini dibatasi oleh hukum yang sifatnya memaksa, sehingga para pihak yang membuat perjanjian harus menaati hukum yang sifatnya memaksa. Suatu perjanjian tidak dapat ditarik kembali selain dengan sepakat kedua belah pihak, atau karena alasan-alasan yang oleh undang-undang dinyatakan cukup untuk itu, perjanjian tidak hanya mengikat untuk hal-hal yang dengan tegas dinyatakan didalamnya, tetapi juga untuk segala sesuatu yang menurut sifat perjanjian, diharuskan oleh kepatutan, kebiasaan atau undang-undang atau yang biasa dikenal sebagai asas itikad baik, yang berarti bahwa kedua belah pihak harus berlaku terhadap yang lain berdasarkan kepatutan di antara orang-orang yang sopan tanpa tipu daya, tanpa tipu muslihat, tanpa akal-akalan, dan tidak hanya melihat pada kepentingan diri sendiri, tetapi juga kepentingan orang lain ${ }^{30}$. Dalam hal ini jika sudah terjadi satu kesepakatan yang tertera dalam aspek yuridis maka kedua belah pihak yang melakukan perjanjian juga sama-sama mempunyai perlindungan secara hukum.

Menurut pasal 1339 KUH Perdata, suatu perjanjian tidak hanya mengikat untuk hal-hal yang dengan tegas dinyatakan dalam perjanjian, tetapi juga untuk segala sesuatu yang menurut sifat perjanjian diharuskan oleh kepatutan, kebiasaan dan undangundang. Dengan demikian, setiap perjanjian diperlengkapi dengan aturan-aturan yang terdapat dalam undang-undang, dalam adat kebiasaan, sedangkan kewajiban-kewajiban yang diharuskan oleh kepatutan juga harus diindahkan ${ }^{31}$,

Ada 3 (tiga) sumber norma yang ikut mengisi suatu perjanjian, yaitu undangundang, kebiasaan dan norma kepatutan. Menurut Pasal 1338 ayat 3 KUH Perdata, semua perjanjian harus dilaksanakan dengan itikad baik. Norma ini merupakan salah satu pengaturan terpenting dalam hukum perjanjian. Dan dalam penerapannya hakim diberikan kekuasaan untuk mengawasi pelaksanaan suatu perjanjian agar jangan sampai pelaksanaan itu melanggar kepatutan dan keadilan. Ini berarti hakim itu berkuasa untuk untuk menyimpang dari isi perjanjian menurut apa yang sudah diperjanjikan oleh para pihak. Jadi jika dalam ayat 1 (satu) Pasal 1338 KUH Perdata tersebut dapat dipandang sebagai suatu syarat atau tuntutan kepastian hukum, maka dalam ayat 3 (tiga) Pasal 1338 KUH Perdata dapat dianggap sebagai suatu tuntutan keadilan ${ }^{32}$.

Perwujudan perlindungan hukum bagi Danamon Simpan Pinjam dapat melalui 2 (dua) macam perlindungan hukum, yaitu:

30 Naja. H.R. Daeng, Pengantar Hukum Bisnis Indonesia, Pustaka Yustisia, Yogyakarta, 2009, hlm. 95.

31 Ibid., hlm. 101.

32 Ibid., hlm. 102. 
1. Perlindungan Hukum Preventif

Pada perlindungan hukum preventif ini, pihak Danamon Simpan Pinjam dalam memberikan kreditnya harus memperhatikan pada proses pemberian kredit yang baik dan sehat, serta analisis yang mendalam serta kepercayaan pihak danamon simpan pinjam terhadap kemampuan nasabah untuk membayar dan melunasi pinjaman didasarkan pada hasil analisa dan penilaian. Penilaian terhadap watak dan kemampuan calon debitur menjadi hal yang utama bagi Danamon Simpan Pinjam dalam awal pemutusan pemberian kredit. Penilaian ini sangat berguna untuk mengetahui itikad baik calon debitor dalam memenuhi kewajiban-kewajibannya sesuai dengan syarat-sy,arat dan atau ketentuan-ketentuan sebagaimana yang diatur dalam perjanjian kredit.

Persoalan agunan ini berkaitan dengan ketentuan pasal 1131 dan 1132 KUH Perdata. Kedua pasal ini membahas tentang piutang-piutang yang diistimewakan. Pasal 1131 KUH Perdata mengatakan bahwa segala kebendaan si berutang, baik yang bergerak maupun tidak bergerak, baik yang sudah ada maupun yang baru akan ada dikemudian hari, menjadi tanggungan untuk segala perikatan perseorangan. Pasal 1132 mengatakan bahwa kebendaan tersebut menjadi jaminan bersama-sama bagi semua orang yang mengutangkan padanya; pendapatan penjualan bendabenda itu dibagi-bagikan menurut keseimbangan, yaitu menurut besarkecilnya piutang masing-masing, kecuali apabila diantara para piutang itu ada alasan-alasan yang sah untuk didahulukan.

Untuk kredit tanpa agunan, karena pihak bank tidak menentukan dari awal apa yang menjadi agunannya dan dalam hal ini memang tidak menggunakan agunan, maka berdasarkan Pasal 1131 dan 1132 KUH Perdata, harta kekayaan milik dari debitur seluruhnya menjadi jaminan terhadap jumlah utang yang harus dibayarkan oleh debitur. Akibatnya jika terjadi wanprestasi dari pihak debitur, maka pihak Bank melakukan eksekusi berdasarkan Pasal 1131 dan 1132 KUH Perdata. Dengan menggunakan kedua pasal tersebut pihak kreditor melakukan penilaian terhadap nilai ekonomi seluruh harta maupun barang-barang berharga milik debitur yang wanprestasi sebagai pelunasan dari sisa prestasinya yang belum terpenuhi.

Diperlukan fomula dari isi perjanjian kredit yang benar-benar dapat dilaksanakan nantinya manakala terjadi kredit macet dan hal-hal diluar kendali pihak kreditor dalam proses penyelesaian kredit maupun dalam hal pelunasan utang. Isi perjanjian kredit yang tepat dan mengikat tadi dituangkan dalam perjanjian kredit yang disetujui pihak debitor. 
Namun ada pasal-pasal yang perlu ditambahkan untuk melengkapi agar nantinya dapat memudahkan dalam proses penyelesaian kredit. Adapun formula atau rancangan dari isi perjanjian kredit tersebut adalah

a. Apabila suatu hari terdapat keadaan tidak terpenuhinya salah satu ketentuan dalam perjanjian kredit atau tidak terbayarnya bunga, pokok angsuran atau kredit macet yang disebabkan tidak mampunya debitor melunasi utangnya maka seluruh usahanya menjadi jaminan dan dapat disita sewaktu-waktu oleh pihak kreditor untuk pelunasan utangnya.

b. Atas semua fasilitas kredit yang diterima oleh Debitor, apabila debitor meninggal dunia maka ahli waris dari Debitor wajib menanggung sisa kredit yang ada untuk melakukan pembayaran bunga, pokok angsuran kepada pihak bank.

c. Pihak Debitor tidak boleh mengalihkan segala bentuk usahanya ataupun utang-piutangnya kepada pihak ketiga tanpa sepengetahuan atau izin dari pihak Bank.

Dasar bagi Bank Penerbit untuk melakukan eksekusi bila terjadi kredit macet tentunya adalah perjanjian yang dibuat pada awalnya suatu perikatan terjadi, yaitu dimana aplikasi permohonan kredit yang anda ajukan disetujui oleh pihak Bank Penerbit. Bila nasabah wanprestasi berdasarkan ketentuanketentuan yang ada dalam perjanjian tersebut, misalnya adanya keterlambatan pembayaran dari pengguna fasilitas kredit, maka pihak bank dapat berpegang pada aplikasi kredit yang disetujui bersama tersebut untuk melakukan eksekusi.

2. Perlindungan Hukum Represif

Perlindungan hukum yang bersifat represif, bertujuan untuk menyelesaikan suatu sengketa yang dapat menimbulkan suatu kerugian. Perlindungan ini digunakan sebagai langkah terhadap kemungkinan timbulnya resiko kerugian dari kegiatan usaha yang dilakukan oleh bank. Perlindungan hukum bagi kreditur yang memanfaatkan kredit tanpa agunan ini lebih luas akibat hukumnya, kredit tanpa jaminan apabila terjadi wanprestasi mengandung lebih besar resiko. Pada lembaga perbankan pada umumnya, menerapkan prinsip kehati-hatian dalam setiap pemberian kredit kepada debitur dengan jalan meminta jaminan atau dikenal dengan kredit dengan jaminan, sebagai salah satu upaya meminimalisir resiko kerugian yang akan diderita sebagai akibat debitur tidak dapat melunasi kreditnya sesuai dengan yang telah diperjanjikan dalam perjanjian kredit $^{33}$.

Dalam kredit tanpa agunan ini ketika terjadi kredit macet maka diperlukan bentuk penyelesaian kredit yang tidak 
merugikan pihak bank maupun pihak debitor itu sendiri karena mengingat jumlah kredit yang diberikan oleh pihak bank tidak terlalu besar. Maka diperlukan sebuah pengadilan kecil seperti halnya pengadilan pada tindak pidana tilang untuk menyelesaikan sengketa atau kasus yang terjadi antara pihak Bank dan nasabahnya dengan biaya yang murah.

Diharapkan dengan adanya pengadilan ini, dapat meminimalkan biaya yang dikeluarkan oleh pihak bank untuk melakukan gugatan terhadap nasabahnya dalam rangka penyelesaian kasus kredit macetnya, sehingga pihak bank tidak banyak mengalami kerugian dan dengan putusan pengadilan tersebut pihak bank dapat melakukan eksekusi terhadap nasabahnya.

\section{Simpulan}

Berdasarkan analisis yang sudah dibahas dapat disimpulkan bahwa perlindungan hukum bagi kreditor dalam pemberian kredit modal kerja kerja tanpa agunan dapat dilakukan melalui: Perlindungan hukum preventif dimana diperlukan fomula dari isi perjanjian kredit yang dapat dilaksanakan nantinya manakala terjadi kredit macet dan hal-hal diluar kendali pihak kreditor dalam proses penyelesaian kredit maupun dalam hal pelunasan utang. Isi perjanjian kredit yang tepat dan mengikat tadi dituangkan dalam perjanjian kredit yang disetujui pihak debitor, serta perlindungan hukum yang bersifat represif, digunakan sebagai langkah terhadap kemungkinan timbulnya resiko kerugian dari kegiatan usaha yang dilakukan oleh bank, diperlukan sebuah pengadilan kecil seperti halnya pengadilan pada tindak pidana tilang untuk menyelesaikan sengketa atau kasus yang terjadi antara pihak bank dan nasabahnya dengan biaya yang murah. Dalam kredit tanpa agunan ini ketika terjadi kredit macet maka diperlukan bentuk penyelesaian kredit yang tidak merugikan pihak bank maupun pihak debitor itu sendiri karena mengingat jumlah kredit yang diberikan oleh pihak bank tidak terlalu besar. Maka diperlukan sebuah pengadilan kecil seperti halnya pengadilan pada tindak pidana tilang untuk menyelesaikan sengketa atau kasus yang terjadi antara pihak Bank dan nasabahnya dengan biaya yang murah.

\section{DAFTAR PUSTAKA}

\section{Buku}

B. Curzon, 1979, Jurisprudence, Macdonal \& Evan Ltd, Estover Plymouth.

Boedi Harsono, 2003, Hukum Agraria

Indonesia, Djambatan, Jakarta.
Budi Untung, 2000, Kredit Perbankan di

Indonesia, Andi, Yogyakarta.

C.S.T. Kansil dan Christine S.T.Kansil, 2002,

Pokok-Pokok Pengetahuan hukum

Dagang Indonesia, Sinar Grafika, Jakarta. 
Edy Putra Ije Aman, 1989, Kredit Perbankan

Suatu Tinjauan Yuridis, Liberty,

Yogyakarta.

Johannes Ibrahim, 2004, Cross Default dan

Cross Collateral sebagai Upaya

Penyelesaian Kredit Bermasalah,

Refika Aditama, Bandung.

Muhammad Djumhana, 2000, Hukum

Perbankan di Indonesia, Citra Aditya

Bakti, Bandung.

Munir Fuady, 2003, Jaminan Fidusia,

Cetakan Ke-dua Revisi, Citra Aditya,

Bandung.

Naja. H.R. Daeng, 2009, Pengantar Hukum

Bisnis Indonesia, Pustaka Yustisia, Yogyakarta.

Permadi Ganda Pradja, 2004, Dasar dan

Prinsip Pengawasan Bank, Gramedia

Pustaka Utama, Jakarta.

Purwahid Patrik dan Kashadi, 2003, Hukum

Jaminan Edisi Revisi dengan

UUHT, Fakultas Hukum Universitas

Diponegoro.

Rachmadi Usman, 2001, Aspek-aspek

Hukum Perbankan di Indonesia,

Gramedia Pustaka Utama, Jakarta.

R. Soebekti, 2001, Hukum Perjanjian, Intermasa, Jakarta.

R. Tjipto Adi Nugroho, 1986, Perbankan,

Masalah Fungsi, Organisasi dan

Ketatalaksanaan, Pradnya Paramita, Jakarta.
Sutan Remmy Syahdeini, 1993, Kebebasan

Berkontrak dan Perlindungan yang Seimbang bagi Para Pihak dalam Perjanjian Kredit Bank, Institut Bankir Indonesia, Jakarta.

Sutarno, 2000, Aspek-aspek Hukum Perkreditan pada Bank, Alfabeta, Bandung.

Zulkarnain Sitompul, 2005, Transparansi Perbankan: Tantangan 2005, Pilars N0.51/TH VII/27 Desember 2004-09 Januari 2005.

\section{Makalah}

Anwar Nasution, Masalah-masalah Sistem Keuangan dan Perbankan Indonesia, Makalah yang disampaikan dalam Seminar Pembangunan Hukum Nasional VIII yang diselenggarakan oleh Badan Pembinaan Hukum Nasional - Departemen Kehakiman dan Hak Asasi Manusia R1, 14-18 Juli di Denpasar.

\section{Peraturan Perundang-undangan}

Pasal 2 UU No. 7 Tahun 1992 sebagaimana diubah dengan UU No. 10 Tahun 1998 tentang Perbankan.

\section{Naskah Internet}

Herdaru Purnomo, Didesak Keluarkan Aturan Etika Penawaran KTA, http// detikFinance.co.id. 